\title{
Influence of Age on the Metabolism of Plasma Low Density Lipoproteins in Healthy Males
}

\author{
Sverker Ericsson, Mats Eriksson, Sigurd Vitols, ${ }^{\star}$ Kurt Einarsson, Lars Berglund, and Bo Angelin \\ Metabolism Unit, Departments of Medicine and Clinical Chemistry, Karolinska Institute at Huddinge University Hospital, S-141 86 \\ Huddinge, Sweden; and *Department of Clinical Pharmacology, Karolinska Hospital, S-104 01, Stockholm, Sweden
}

\begin{abstract}
The plasma concentration of the atherogenic low density lipoproteins (LDL) increases with age. To clarify the mechanism of this change, we studied the kinetics of autologous ${ }^{125}$ I-LDL apolipoprotein B (apo B) in 41 normolipidemic, nonobese healthy males. For comparison, they were divided into three age groups: young, 21-39 yr $(n=18)$, middle-aged, 40-59 yr ( $n$ $=11)$, and old, 60-80 yr $(n=12)$. The levels of plasma LDL cholesterol and LDL apo $B$ increased from respectively $3.4 \pm 0.1(\mathrm{SEM}) \mathrm{mmol} / \mathrm{liter}$ and $86 \pm 2 \mathrm{mg} / \mathrm{dl}$ in the young to $4.1 \pm 0.1 \mathrm{mmol} / \mathrm{liter}$ and $95 \pm 3 \mathrm{mg} / \mathrm{dl}$ in the old $(P<0.01)$, and this increase was linked to a progressively decreased $(r$ $=-0.38, P<0.02)$ fractional catabolic rate of $L D L$ apo $B$ $(0.348 \pm 0.010$ pools per day in the young vs. $0.296 \pm 0.009$ pools per day in the old, $P<0.01$ ). The production rate of $L D L$ apo $B$ did not differ significantly between the groups. The reduced fractional catabolic rate of LDL apo B in the old was not associated with a decrease in binding affinity of the LDL particle to its receptor, as judged from its ability to compete for ${ }^{125} \mathrm{I}-\mathrm{LDL}$ fibroblast binding. When hepatic LDL receptor expression was stimulated by cholestyramine treatment in six old males, their LDL apo B fractional catabolic rate increased to the levels observed in the young subjects. We conclude that the increase in LDL which normally occurs with age is explained by a reduced capacity for its removal, and hypothesize that this is mediated via a reduced hepatic LDL receptor expression. ( $J$. Clin. Invest. 1991. 87:591-596.). Key words: apolipoprotein B - cholesterol • low density lipoprotein kinetics • low density lipoprotein receptors
\end{abstract}

\section{Introduction}

Elevated levels of plasma total and low density lipoproteins (LDL) cholesterol are known to be associated with an increased risk for coronary heart disease (1), and the lowering of LDL cholesterol by pharmacological intervention has been demonstrated to reduce this risk $(2,3)$. Since plasma LDL cholesterol levels increase with age $(4,5)$, and since LDL cholesterol persists as a predictor of risk also in old age $(1,6)$, much interest has recently been focused on possible mechanisms for this agerelated increase in LDL cholesterol levels (7).

Address reprint requests to Dr. Ericsson, Department of Medicine, Huddinge University Hospital, S-141 86 Huddinge, Sweden.

Received for publication 22 May 1990 and in revised form 4 September 1990.

J. Clin. Invest.

(c) The American Society for Clinical Investigation, Inc.

$0021-9738 / 91 / 02 / 0591 / 06 \$ 2.00$

Volume 87, February 1991, 591-596
The plasma concentration of LDL cholesterol is determined by the balance between synthesis and catabolism of the lipoprotein particle $(8,9)$. The production of LDL is dependent on the metabolism of their precursor, the triglyceride-rich very low density lipoproteins (VLDL), whereas normally a major part (60-80\%) of LDL removal from plasma takes place by a high-affinity process involving specific cell surface receptors, the LDL receptors (10). These receptors are expressed in all human cells, particularly in the adrenals, gonads, and liver, and in actively dividing cells $(10,11)$. The liver contains the highest total number of LDL receptors, and the hepatic LDL receptor activity can be modulated by pharmacological, nutritional, and hormonal factors (10-13). Some animal studies have indicated that the hepatic LDL receptor expression may decline with increasing age (13), but the information from human studies has not been conclusive. Thus, retrospective analysis of data compiled from several studies has indicated that the fractional catabolic rate $(F C R)^{1}$ of LDL decreases with aging $(7,14)$, but it has been difficult to determine the importance of this phenomenon as a primary factor $(14,15)$.

In the present study, we have characterized the metabolism of autologous ${ }^{125}$ I-LDL apolipoprotein B (apoB) in healthy normolipidemic, nonobese adult human males. The results demonstrate that the increase in LDL cholesterol with age is due to a lower FCR of this lipoprotein, whereas no relation to production rate or changes in the binding properties of LDL was observed. Furthermore, reversal of the age-related decrease in the FCR of LDL apo B could be achieved through stimulation of cholesterol elimination by cholestyramine treatment.

\section{Methods}

Subjects and experimental procedure. A total of 41 healthy volunteers participated in the study. They were all males of Scandinavian origin, mostly medical students or hospital staff members; the healthy old men were recruited from a senior citizen group outside the hospital. None of the volunteers were obese, and the relative body weights (RBW) ranged from $82 \%$ to $111 \%$ with a mean of $97 \%$. All participants were normolipidemic, with plasma cholesterol and triglyceride levels below the 95th percentile (16). There was no clinical or laboratory evidence of thyroid, kidney, heart, or liver disease; diabetes mellitus; or alcohol overconsumption in these subjects. None used medication of any kind.

The volunteers were hospitalized in the metabolic ward or followed closely as outpatients. For $5 \mathrm{~d}$ before and during the study they were given a standardized diet of natural type $(17,18)$. About $35 \%$ of the energy content was supplied as fat, most of which contained saturated fatty acids. The major part of the carbohydrates, which accounted for $45 \%$ of the calories, was supplied as starch. The energy intake, calculated from standard foodstuff tables, was adjusted to keep the body weight constant. The daily intake of cholesterol was $\approx 0.5 \mathrm{mmol}(200$

1. Abbreviations used in this paper: FCR, fractional catabolic rate; $R B W$, relative body weight; $U / P$, urine to plasma. 
$\mathrm{mg}$ ). Potassium iodide, $200 \mathrm{mg}$ daily, was given orally $5 \mathrm{~d}$ before and during the study to suppress uptake of radioiodine by the thyroid gland.

A subgroup of six older men (mean age, $68 \pm 1$ yr) was restudied under identical conditions $3 \mathbf{w k}$ after the initiation of treatment with cholestyramine (Questran, Bristol-Myers Co., New York), $8 \mathrm{~g}$ b.i.d.

Informed consent was obtained from each subject, and the ethical aspects of the study were approved by the Ethical Committee at Huddinge University Hospital.

Lipoprotein preparation, quantitation, and turnover. After an overnight fast, $\approx 100 \mathrm{ml}$ of blood was drawn into EDTA-containing tubes, and plasma was obtained by low-speed centrifugation in the cold. LDL (density $1.02-1.063 \mathrm{~g} / \mathrm{ml}$ ) were prepared by sequential ultracentrifugation and labeled with ${ }^{125} \mathrm{I}$, using the iodine monochloride method as described for lipoproteins $(19,20)$. The specific activity of the ${ }^{125}$ I-LDL varied from 150 to $450 \mathrm{cpm} / \mathrm{ng}$ of protein. $>97 \%$ of the radioactivity was TCA-precipitable and $<3 \%$ was extractable with ether. As judged from sodium dodecyl sulfate polyacrylamide gel electrophoresis (SDSPAGE), the radioactivity was present almost exclusively in apo $B$. The labeled LDL were sterilized by passage through two $0.45-\mu \mathrm{m}$ filters, and $30-60 \mu \mathrm{Ci}(1.1-2.2 \mathrm{MBq})$ of ${ }^{125} \mathrm{I}-\mathrm{LDL}$ apoB was reinjected into the patient as described previously (18). Blood samples were collected in EDTA tubes at $10 \mathrm{~min}$, and at $2,4,6,8,10,12,24$, and $36 \mathrm{~h}$ after the injection, whereafter samples were collected daily for $14 \mathrm{~d}$. The urine was collected in 24-h portions during the whole study.

Lipoprotein quantitation was performed by a combination of ultracentrifugation and precipitation $(21,22)$ on at least two occasions during the study. Briefly, plasma obtained under fasting conditions was spun at $35,000 \mathrm{rpm}$ for $18 \mathrm{~h}$ at $4^{\circ} \mathrm{C}$ in an ultracentrifuge (Centrikon T-2060, Contron Roche, Zurich, Switzerland) equipped with a 45.6 rotor. The tubes were sliced and the supernatant fraction as well as the infranatant were analyzed for cholesterol and triglyceride content using standard enzymatic techniques (Boehringer-Mannheim, Mannheim, Federal Republic of Germany). A portion of the infranatant was treated with phosphotungstic acid in order to precipitate apo B-containing lipoproteins. Protein content was measured according to Lowry et al. (23). The level of LDL apoprotein (LDL apo B) was determined by multiplying the LDL cholesterol level with the protein/cholesterol ratio in the isolated LDL (18).

The FCR of ${ }^{125} \mathrm{I}-\mathrm{LDL}$ apo B was calculated from the slope of the plasma radioactivity decay curve using the two-compartment model of Matthews (24). In addition, FCR was also calculated independently from the urine/plasma (U/P) ratio (18). The absolute catabolic rate of LDL apo B, expressed as milligrams of apoprotein synthesized per day normalized for body weight, was estimated according to Langer et al. $(25)$, as described $(18,26)$

Fibroblast assay of $L D L$ degradation. Human fibroblasts grown in monolayer culture were preincubated in a medium containing $10 \%$ human lipoprotein-deficient serum for $48 \mathrm{~h}$ before assay to induce maximal LDL receptor expression as described $(18,27)$. To assess the affinity of LDL from the different individuals for the LDL receptor, the cells were incubated with $15 \mu \mathrm{g} / \mathrm{ml}$ of ${ }^{125} \mathrm{I}-\mathrm{LDL}$ (prepared from a young normal) in the absence and presence of $33 \mu \mathrm{g} / \mathrm{ml}$ of unlabeled LDL from the different individuals. After $6 \mathrm{~h}$ at $37^{\circ} \mathrm{C}$ the degradation rate of ${ }^{125} \mathrm{I}-\mathrm{LDL}$ was determined after precipitation of the cell medium with TCA (27). The percentage inhibition of the cellular ${ }^{125}$ I-LDL degradation rate in the presence of unlabeled LDL was used as an estimate of the affinity of the LDL particle for the LDL receptor (18).

Statistical analysis. Data are presented as means \pm SEM. The signifcance of differences was tested by two-tailed $t$ test. Correlations were tested by calculating the correlation coefficient, $r$. Multiple stepwise regression was performed using an $F$ value of 4.0 to include or exclude independent variables.

\section{Results}

In the present study of nonobese healthy males, the levels of plasma total and LDL cholesterol rose progressively with age $(r$
$=+0.30, P=0.05$; and $r=+0.37, P=0.02$; respectively). This age-related change was not related to other variables such as absolute or relative body weight or triglyceride concentration. To facilitate further comparison, the subjects were subdivided into three groups according to their age: young $(n=18), 20-39$ yr; middle-aged $(n=11), 40-59 \mathrm{yr}$; and old $(n=12), 60-80 \mathrm{yr}$ (Table I).

The plasma concentration of LDL apo B increased in parallel with the LDL cholesterol level. However, the cholesterol/ protein ratio in LDL was not constant but increased with higher LDL cholesterol values (from $1.52 \pm 0.04$ in the young to $1.70 \pm 0.06$ in the old, $P<0.05$ ), indicating that the LDL particle in the old males was somewhat enriched in cholesterol.

The metabolism of LDL apo B was investigated utilizing autologous radiolabeled lipoproteins (Table II). The figures for FCR obtained from analysis of the U/P ratios were in excellent agreement with the data gained from analysis of the plasma radioactivity dieaway curves $(r=+0.88, P<0.001)$; in the following, all data represent the results derived from plasma radioactivity measurements.

There were no correlations between absolute or relative body weight and kinetic parameters for ${ }^{125} \mathrm{I}-$ LDL apo B. When tested against the independent variables-age, body weight, RBW, and total triglycerides-only age was a significant explanatory variable. The FCR of LDL apo B, i.e., the fraction of the LDL apo B pool being removed each day, decreased from $0.348 \pm 0.010$ pools per day in the young to $0.296 \pm 0.009$ pools per day in the old $(P<0.01)$. Although there was no significant difference between the young and middle-aged subjects, Fig. 1 $A$ shows that the decrease in LDL apo B-FCR progressed with age in the group as a whole $(r=-0.38, P=0.01)$. Interestingly, the synthesis of the LDL apo B did not increase with age, however (Fig. $1 B$ ). Rather, there was a tendency for the calculated synthesis to be lower in the old subjects $(12.4 \pm 0.5 \mathrm{mg} / \mathrm{kg}$ per d) than in the young $(13.2 \pm 0.4 \mathrm{mg} / \mathrm{kg}$ per $\mathrm{d}, P=0.2)$ and middleaged $(14.5 \pm 0.7 \mathrm{mg} / \mathrm{kg}$ per d, $P=0.1)$. Thus, the decreased FCR of LDL apo $B$ in the old subjects was clearly not secondary to an increased production rate. The importance of $\mathrm{LDL}$ apo $\mathrm{B}$ FCR for the variation in LDL cholesterol levels in the present

Table I. Clinical Data and Plasma Lipid Levels of the Subjects

\begin{tabular}{lccc}
\hline & $\begin{array}{c}\text { Young } \\
(n=18)\end{array}$ & $\begin{array}{c}\text { Middle aged } \\
(n=11)\end{array}$ & $\begin{array}{c}\text { Old } \\
(n=12)\end{array}$ \\
\hline Age $(y r)$ & $28 \pm 1$ & $48 \pm 2$ & $68 \pm 2$ \\
Body weight $(k g)$ & $80 \pm 2$ & $77 \pm 3$ & $75 \pm 2$ \\
$\begin{array}{l}\text { Relative body weight* }(\%) \\
\text { Plasma cholesterol }\end{array} \quad 95 \pm 2$ & $96 \pm 2$ & $100 \pm 2$ \\
$\quad(m m o l / l i t e r)$ & & & \\
$\quad \begin{array}{lll}\text { Total } \\
\text { LDL }\end{array}$ & & & \\
$\quad$ HDL & $4.80 \pm 0.18$ & $5.14 \pm 0.27$ & $5.44 \pm 0.20^{\ddagger}$ \\
$\quad$ VLDL & $3.37 \pm 0.14$ & $3.76 \pm 0.25$ & $4.05 \pm 0.15^{\S}$ \\
Plasma triglycerides & $1.12 \pm 0.05$ & $1.02 \pm 0.07$ & $1.08 \pm 0.06$ \\
$\quad(m m o l / l i t e r)$ & $0.31 \pm 0.05$ & $0.36 \pm 0.06$ & $0.31 \pm 0.06$ \\
& & & $1.21 \pm 0.12$
\end{tabular}

All values are given as mean \pm SEM. To convert millimoles per liter to milligrams per deciliter, multiply cholesterol by 38.7 and triglycerides by 88.5 .

* Calculated as body weight $(\mathrm{kg}) /[$ height $(\mathrm{cm})-100] \times 100 \%$.

${ }^{\ddagger} P<0.05 ;{ }^{\S} P<0.01$ vs. young (Student's unpaired $t$ test). 


\begin{tabular}{|c|c|c|c|c|}
\hline & LDL apo B & $\begin{array}{l}\text { LDL apo B } \\
\text { pool size }\end{array}$ & LDL apo B-FCR & $\begin{array}{l}\text { LDL apo B } \\
\text { production rate }\end{array}$ \\
\hline & $m g / d l$ & $m g / k g$ & pools per day & $m g / k g$ per day \\
\hline Young $(n=18)$ & $86 \pm 2$ & $38.1 \pm 1.0$ & $0.348 \pm 0.010$ & $13.2 \pm 0.4$ \\
\hline Middle-aged $(n=11)$ & $93 \pm 6$ & $40.7 \pm 1.9$ & $0.342 \pm 0.018$ & $13.7 \pm 0.5$ \\
\hline Old $(n=12)$ & $95 \pm 3^{\ddagger}$ & $41.8 \pm 1.4^{*}$ & $0.296 \pm 0.009^{\S}$ & $12.4 \pm 0.5$ \\
\hline
\end{tabular}

Values are given as mean \pm SEM. FCR calculated from plasma radioactivity decay curve. ${ }^{*} P<0.05 ;{ }^{\ddagger} P<0.01 ;{ }^{\S} P<0.005$ vs. young (Student's unpaired $t$ test).

series of healthy, nonobese males was further evident from the fact that there was a highly significant negative correlation $(r$ $=-0.71, P<0.001)$ between these two variables, whereas there was no significant relationship $(r=0.095)$ between LDL cholesterol and LDL apo B production rate (Fig. 2). A similar correlation was observed between LDL apo B-FCR and LDL apo B level $(r=-0.54, P<0.005)$.

The observed decrease in FCR of LDL apo B with age might result from a reduced LDL receptor activity or, alternatively, from a decreased affinity of the LDL particle itself for its receptor. Apart from the increased cholesterol/protein ratio, there were no significant differences in lipid composition, such as triglyceride/protein ratio, between LDL obtained from subjects of varying age (data not shown). To test directly the hypothesis that LDL isolated from the old have a lower affinity for the LDL receptor, the ability of individual LDL preparations to compete for degradation of ${ }^{125}$ I-LDL by cultured fibroblasts was studied: LDL isolated from seven young and eight old subjects were tested during the same experiment (Table III). There was no difference in the inhibition of cellular ${ }^{125} \mathrm{I}-$ LDL degradation of the LDL particles from the old (67\% inhibition) compared with those obtained from the young subjects (64\% inhibition).

The increase in LDL cholesterol with age in nonobese males could thus be explained by a decrease in LDL apo B elimination, presumably as the result of a reduced activity of LDL receptors. In order to evaluate whether this apparent loss of degradation capacity with age was reversible, six old males were treated with cholestyramine for $3 \mathrm{wk}$. This drug, which by trapping intestinal bile acids creates an enhanced hepatic demand for cholesterol, increased the FCR of ${ }^{125} \mathrm{I}-\mathrm{LDL}$ apo B from $0.286 \pm 0.013$ to $0.326 \pm 0.023$ pools per day $(P<0.02$; Fig. $3)$, resulting in a reduction of LDL cholesterol levels from $4.2 \pm 0.2$ to $2.5 \pm 0.2 \mathrm{mmol} / \mathrm{liter}(P<0.005)$. Thus, when provided the stimulus of enhanced cholesterol elimination, the old subjects could still eliminate LDL to the same extent as the young.

\section{Discussion}

The present study was undertaken to characterize the possible changes in LDL apo B metabolism normally occurring with increasing age. To minimize the potential effects of changes in confounding factors, such as body weight and hormonal status, we chose to study a genetically homogeneous, nonobese, normolipidemic, entirely male population ranging in age from 21 to $80 \mathrm{yr}$. In agreement with studies of the general population (4, 16 ), we could demonstrate an increase in serum cholesterol levels with age also in this carefully selected group of healthy subjects. The increased serum cholesterol levels were solely due to a higher concentration of LDL cholesterol, since the other lipoprotein fractions did not differ between the three age groups $(21-39,40-59$, and $60-80 \mathrm{yr})$. The results of the present study give evidence that this increase in LDL cholesterol levels was primarily related to a reduced FCR of the LDL apo B with age. The tendency to an increased pool of circulating LDL apo B occurs in spite of a tendency to a decreased rate of synthesis of this lipoprotein. This fact argues strongly against the alternative hypothesis, namely, that the decreased FCR is secondary to the increase in LDL apoB pool size (15).

The demonstration of a reduced FCR of LDL apo B as a major determinant of the increased LDL levels which occur with increasing age in normal individuals is in agreement with the mechanism suggested by Miller (7). From his analysis of several published investigations, it was implied that the produc-
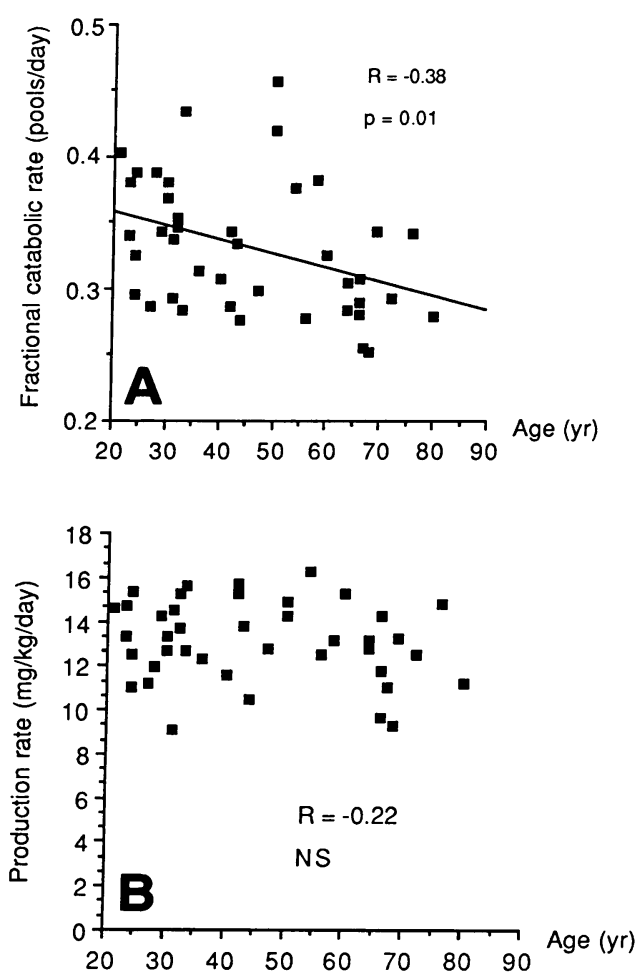

Figure 1. (A) Relation between age and fractional catabolic rate of autologous ${ }^{125}$ I-LDL apoB in 41 healthy, nonobese males. $(B)$ Relation between age and estimated synthesis rate of LDL apoB. 

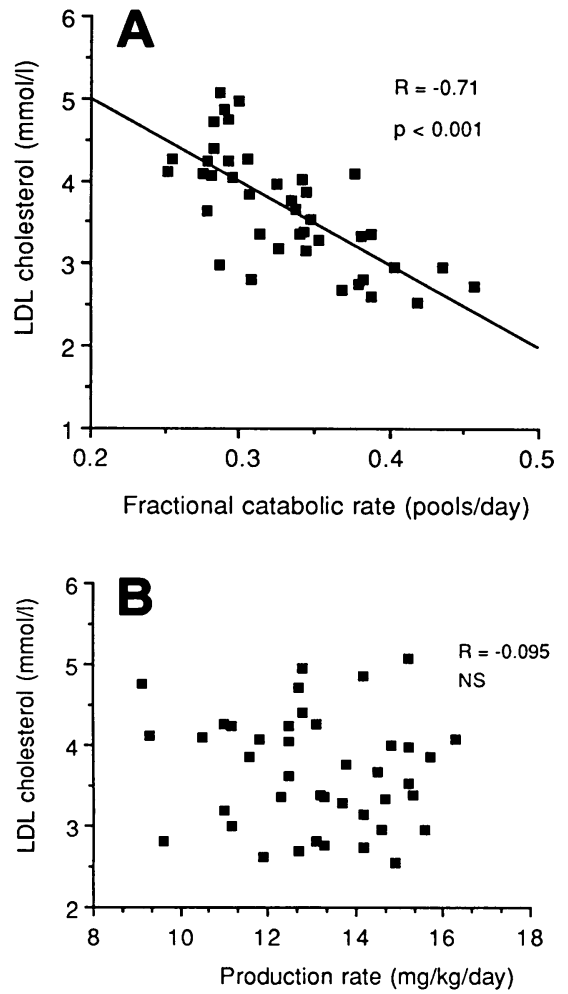

Figure 2. (A) Relation between LDL apoB FCR and plasma LDL cholesterol level in 41 healthy, nonobese males of varying age. $(B)$ Relation between estimated synthesis rate of LDL apoB and plasma LDL cholesterol level. To convert millimoles per liter (l) to milligrams per deciliter, multiply LDL cholesterol by 38.7 .

tion rate of LDL does not substantially affect LDL cholesterol levels when comparing normal subjects of varying age. Also in the study by Grundy et al. (14), where middle-aged, slightly overweight males were compared to nonobese young individuals, a decrease in FCR with age was reported. However, the synthesis of LDL apo B was simultaneously elevated in the middle-aged subjects in that study, so it was not possible to conclude whether or not the decreased FCR was a primary event. It is evident that the design of this recent study is not fully comparable to that of the present work: thus, when compared to the young individuals, the middle-aged subjects studied by Grundy et al. (14) displayed higher plasma triglyceride levels in addition to their higher ideal body weights. It should also be pointed out, that the difference in LDL cholesterol and LDL apo B between young and middle-aged subjects was not significant in our study. A period of weight gain between the ages 30 and $40 \mathrm{yr}$ is relatively common in males, which may well contribute to an increased LDL synthesis (presumably via an increased VLDL production). Even if great care was taken to ensure comparable body weights between the various groups of subjects in the present study, the body composition may change with age despite an unchanged RBW (28). However, even when recalculating the data on the basis of estimated fatfree mass (28), there was no significant difference in LDL apo B production rate between the three groups (data not shown). Thus, although the data of the present study by no means exclude the possible relevance of an enhanced LDL synthesis as a mechanism for the development of a moderate LDL choles-
Table III. Comparison of the Inhibitory Effect of Isolated LDL Preparations on the Degradation of Standard ${ }^{125}$ I-LDL in Cultured Fibroblasts

\begin{tabular}{lc} 
Source of added LDL & $\begin{array}{c}\text { Degradation } \\
\text { of }{ }^{125} \text { I-LDL* }\end{array}$ \\
\hline No addition & $\%$ \\
Young $(30 \pm 3 \mathrm{yr} ; n=7)$ & 100 \\
Old $(68 \pm 3 \mathrm{yr} ; n=8)$ & $36 \pm 1$ \\
\end{tabular}

Values are given as mean \pm SEM.

* Human fibroblasts in monolayer culture were preincubated in human lipoprotein-deficient serum-containing medium. After $48 \mathrm{~h}$, the medium was replaced with fresh medium and the cells incubated with $15 \mu \mathrm{g} / \mathrm{ml}$ of ${ }^{125} \mathrm{I}-\mathrm{LDL}$ as described in Methods. Unlabeled LDL, isolated from young and old normal subjects, were added to a final concentration of $33 \mu \mathrm{g} / \mathrm{ml}$. The degradation of ${ }^{125} \mathrm{I}-\mathrm{LDL}$ was determined and expressed in relation to that observed in the absence of added unlabeled LDL ( $100 \%$, corresponding to $1,285 \mathrm{ng} / \mathrm{mg}$ per $\mathrm{h}$ ). Each figure represents the average from duplicate incubations.

terol elevation in the general population $(8,9,14)$, the current results do establish the presence of an independent reduction in LDL apo B-FCR with advancing age in nonobese males.

The next step in our study was to evaluate the nature of the reduced FCR of LDL in the old. As discussed above, the reduction could not be explained by an increased production rate and a secondary saturation of removal pathways. An increased removal of VLDL and VLDL remnants by LDL receptors may block LDL uptake. However, since VLDL levels were not different between the various age groups in our study, this possibility is less likely. Several authors have hypothesized that changes in the composition of the LDL particle may affect its affinity for the LDL receptor $(29,30)$, and we were in fact able to demonstrate a higher proportion of cholesterol in relation to protein in LDL isolated from the old males. Such a change could affect the exposure of binding domains of the apolipoprotein, and ultimately result in a particle with altered receptor-binding properties. When this hypothesis was tested directly, however, we were not able to detect any reduction in the binding affinity of LDL from old males compared to young; if anything, the LDL from the old subjects tended to have a slightly higher affinity for the LDL receptor.

The most plausible explanation for the decrease in LDL apo B catabolism with age is thus reduction of LDL receptor activity, presumably in the liver. Although the hepatic blood flow may be somewhat reduced in old subjects (31), the fact

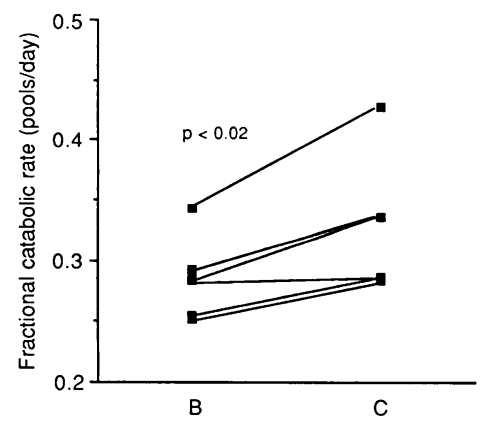

Figure 3. FCR of autologous ${ }^{125} \mathrm{I}-\mathrm{LDL}$ apoB before $(B)$ and after $(C) 3$ wk of treatment with cholestyramine, $8 \mathrm{~g}$ b.i.d., in six healthy, nonobese elderly males (mean age, $68 \pm 1 \mathrm{yr})$ 
that the hepatic LDL receptors are exposed to concentrations of LDL far above saturation (11) would speak against any major importance of circulatory changes. For the same reason, reduced affinity of the binding of LDL due to changes in the receptors themselves would probably also not influence the LDL receptor-mediated elimination considerably. Instead, a diminished number of functioning LDL receptors, and possibly a prolonged turnover time of the recirculating LDL receptors, would be the most plausible explanation for a reduced hepatic LDL uptake. A reduced expression of LDL receptors on liver cell membranes has been demonstrated to occur with increasing age in the dog, swine, and monkey $(13,32)$. Definite extension of this hypothesis to humans must obviously await direct determinations of LDL binding activity in the human liver.

Loss of hepatic LDL receptor activity with increasing age could be either irreversible and due to a general "senescence" of the liver cells, or reversible and thus secondary to other agerelated changes of metabolism. Although a progressive decrease of the maximal capacity to express cell surface LDL receptors has been demonstrated in aging cultured human fibroblasts in vitro (33), we find the former possibility less likely. Thus, cells obtained from individuals of varying age in vivo, e.g., isolated lymphocytes or skin fibroblasts, do not display such a loss of LDL receptor function $(34,35)$. Furthermore, our direct demonstration of an increase in LDL apo B-FCR in response to cholestyramine treatment in the old subjects, reaching values similar to those observed in normal young males (Fig. 3), clearly emphasizes the considerable capacity for "up-regulation" of hepatic LDL receptors which also exists in aged individuals. Further support for this concept is gained from the drastic increase in LDL apo B-FCR observed in old males treated with pharmacologic doses of estrogen due to cancer of the prostate (18). Thus, we would favor the hypothesis that the reduced FCR of LDL apo B in the elderly is a consequence of down-regulation of hepatic LDL receptor expression.

Possible mechanisms for such a suppression of LDL receptor expression with age can only be speculated upon. Although no difference in hepatic cholesterol levels has been reported between patients of varying age with gallstone disease (36), there is evidence of a gradual accumulation of cholesterol in many other tissues with advancing age (37). The possible importance of a "Westernized" diet, rich in saturated fat and cholesterol, for the hepatic LDL receptor activity when consumed over long periods of time has been discussed by several groups $(9,14,38)$. In this context, it is of interest to note that bile acid synthesis decreases with age in normal humans (17). Furthermore, suppression of bile acid synthesis-by treatment with chenodeoxycholic acid-reduces the FCR of plasma LDL apo $B$ and slightly increases LDL cholesterol levels (39-41). An attractive hypothesis therefore states that the reduced hepatic lipoprotein receptor expression occurring with age is the consequence of a reduced hepatic demand for cholesterol owing to a reduced bile acid synthesis. The "normalizing" effect of cholestyramine treatment in the old subjects would be in good agreement with such a view. However, alternate or additional mechanisms may well be of importance: for example, age-dependent hormonal changes, such as reduced concentrations of growth hormone (42), may well be involved. Thus, further studies should be aimed at exploring the possible relevance of these alternative mechanisms. The consistent effect of age on LDL apo B metabolism, and also the fact that it may be reverted by selective therapy are, however, of practical importance and may be relevant in the discussion of possible intervention also in the elderly $(43,44)$.

\section{Acknowledgments}

The skillful technical assistance of Ms. Tatiana Egereva, Ms. Lilian Larsson, and Ms. Sabine Süllow, the manuscript preparation by Ms. Lena Ericsson, and the statistical analysis performed by Dr. Peter Henriksson are gratefully acknowledged.

This study was supported by grants from the Swedish Medical Research Council (03X-7137), the King Gustaf V and Queen Victoria Foundation, the Loo and Hans Osterman Foundation, and the Karolinska Institute.

\section{References}

1. Castelli, W. P., R. J. Garrison, W. F. Wilson, R. D. Abbott, S. Kalousdian, and W. B. Kannel. 1986. Incidence of coronary heart disease and lipoprotein cholesterol levels: the Framingham Study. JAMA (J. Am. Med. Assoc.). 256:2835-2838.

2. Lipid Research Clinics Program. 1984. The Lipid Research Clinics Primary Prevention Trial Results. I. Reduction in incidence of coronary heart disease. JAMA (J. Am. Med. Assoc.). 251:351-364.

3. Frick, M. H., O. Elo, K. Haapa, O. P. Heinonen, P. Heinsalmi, P. Helo, J. K. Huttunen, P. Kaitaniemi, P. Koskinen, V. Manninen, et al. 1987. Helsinki Heart Study: primary-prevention trial with gemfibrozil in middle-aged men with dyslipidemia. Safety of treatment, changes in risk factors, and incidence of coronary heart disease. $N$. Engl. J. Med. 317:1237-1245.

4. Heiss, G., I. Tamir, C. E. Davis, H. A. Tyroler, B. M. Rifkind, G. Schonfeld, D. Jacobs, and I. D. Frantz. 1980. Lipoprotein-cholesterol distributions in selected North American populations: the Lipid Research Clinics Program Prevalence Study. Circulation. 61:302-315.

5. Abbott, R. D., R. J. Garrison, P. W. Wilson, F. H. Epstein, W. P. Castelli, M. Feinleib, and C. LaRue. 1983. Joint distribution of lipoprotein cholesterol classes: the Framingham Study. Arteriosclerosis. 3:260-272.

6. Castelli, W. P., W. F. Wilson, D. Levy, and K. Anderson. 1989. Cardiovascular risk factors in the elderly. Am. J. Cardiol. 63:12H-19H.

7. Miller, N. E. 1984. Why does plasma low density lipoprotein concentration in adults increase with age? Lancet. $i: 263-267$.

8. Havel, R. J. 1984. The formation of LDL: mechanisms and regulation. $J$. Lipid. Res. 25:1570-1576.

9. Vega, G. L., and S. M. Grundy. 1987. Mechanisms of primary hypercholesterolemia in humans. Am. Heart. J. 113:493-502.

10. Brown, M. S., and J. L. Goldstein. 1986. A receptor-mediated pathway for cholesterol homeostasis. Science (Wash. DC). 232:34-47.

11. Rudling, M., E. Reihnér, K. Einarsson, S. Ewerth, and B. Angelin. 1990. Low density lipoprotein receptor binding activity in human tissues: quantitative importance of hepatic receptors and evidence for regulation of their expression in vivo. Proc. Natl. Acad. Sci. USA. 87:3469-3473.

12. Brown, M. S., and J. L. Goldstein. 1983. Lipoprotein receptors in the liver: control signals for plasma cholesterol traffic. J. Clin. Invest. 72:743-747.

13. Mahley, R. W., and T. L. Innerarity. 1983. Lipoprotein receptors and cholesterol homeostasis. Biochim. Biophys. Acta. 737:197-222.

14. Grundy, S. M., G. L. Vega, and D. W. Bilheimer. 1985. Kinetic mechanisms determining variability in low density lipoprotein levels and rise with age. Arteriosclerosis. 5:623-630.

15. Meddings, J. B., and J. M. Dietschy. 1986. Regulation of plasma levels of low density lipoprotein cholesterol: interpretation of data on low density lipoprotein turnover in man. Circulation. 74:805-814.

16. Jungner, I., and E. Steiner. 1988. Epidemiologisk undersökning av lipider och lipoproteiner (Epidemiological studies on lipids and lipoproteins). Hygiea. 97:193. (Abstr.)

17. Einarsson, K., K. Nilsell, B. Leijd, and B. Angelin. 1985. Influence of age on secretion of cholesterol and synthesis of bile acids by the liver. N. Engl. J. Med. 313:277-282.

18. Eriksson, M., L. Berglund, M. Rudling, P. Henriksson, and B. Angelin. 1989. Effects of estrogen on low density lipoprotein metabolism in males: shortterm and long-term studies during hormonal treatment of prostatic carcinoma. $J$. Clin. Invest. 84:802-810.

19. McFarlane, A. S. 1958. Efficient trace-labelling of proteins with iodine. Nature (Lond.). 182:53. 
20. Bilheimer, D. W., S. Eisenberg, and R. I. Levy. 1972. The metabolism of very low density lipoprotein proteins. Biochim. Biophys. Acta. 260:212-221. 21. Carlson, K. 1973. Lipoprotein fractionation. J. Clin. Pathol. 26(Suppl. 5):32-7.

22. Lopes-Virella, M. F., P. Stone, S. Ellis, and J. A. Colwell. 1977. Cholesterol determination in high-density lipoproteins separated by three differen methods. Clin. Chem. 23:882-884.

23. Lowry, O. H., N. J. Rosebrough, A. L. Farr, and R. J. Randall. 1951 Protein measurement with the Folin phenol reagent. J. Biol. Chem. 193:265-275.

24. Matthews, C. M. E. 1957. The theory of tracer experiments with iodine 131-labeled plasma proteins. Phys. Med. Biol. 2:36-53.

25. Langer, T., W. Strober, and R. I. Levy. 1972. The metabolism of low density lipoprotein in familial type II hyperlipoproteinemia. J. Clin. Invest. 51:1528-1536.

26. Kesäniemi, Y. A., and S. M. Grundy. 1982. The significance of low density lipoprotein production in the regulation of plasma cholesterol level in man. $J$. Clin. Invest. 70:13-22.

27. Goldstein, J. L., and M. S. Brown. 1974. Binding and degradation of low density lipoproteins by cultured human fibroblasts: comparison of cells from a normal subject and from a patient with homozygous familial hypercholesterolemia. J. Biol. Chem. 249:5153-5162.

28. Friis-Hansen, B. 1965. Hydrometry of growth and aging. In Human Body Composition. J. Brozek, editor. Pergamon Press, Oxford. 191-209.

29. Witztum, J. L., S. G. Young, R. L. Elam, T. E. Carew, and M. Fischer. 1985. Cholestyramine induced changes in low density lipoprotein composition and metabolism. I. Studies in guinea pigs. J. Lipid. Res. 26:92-102.

30. Aviram, M., S. Lund-Katz, M. C. Phillips, and A. Chait. 1988. Influence of the triglyceride content of low density lipoprotein on the interaction of apolipoprotein B-100 with cells. J. Biol. Chem. 32:16842-16848.

31. Dice, J. F., and S. A. Goff. 1988. Aging and the liver. In The Liver: Biology and Pathology. I. M. Arias, W. B. Jakoby, H. Popper, D. Schachter, D. A. Shafritz, editors. Raven Press, New York. 1245-1258.

32. Mahley, R. W. D. Y. Hui, T. L. Innerarity, and K. H. Weisgraber. 1981. Two independent lipoprotein receptors on hepatic membranes of the dog, swine, and man: apo-B,E and apo-E receptors. J. Clin. Invest. 68:1197-1206.

33. Lee, H.-C., M. A. Paz, and P. M. Gallop. 1982. Low density lipoprotein receptor binding in aging human diploid fibroblasts. J. Biol. Chem. 257:8912 8918.

34. Bilheimer, D. W., Y. K. Ho, M. S. Brown, R. G. W. Anderson, and J. L. Goldstein. 1978. Genetics of the low density lipoprotein receptor: diminished receptor activity in lymphocytes from heterozygotes with familial hypercholesterolemia. J. Clin. Invest. 61:678-696.

35. Bierman, E. L. J. J. Albers, and A. Chait. 1979. Effect of donor age on the binding and degradation of low density lipoproteins by cultured human arterial smooth muscle cells. J. Gerontol. 34:438-488.

36. Ahlberg, J., B. Angelin, and K. Einarsson. 1981. Hepatic 3-hydroxy-3methylglutaryl coenzyme A reductase activity and biliary lipid composition in man: relation to cholesterol gallstone disease and effect of cholic acid and chenodeoxycholic acid treatment. J. Lipid. Res. 22:410-422.

37. Crouse, J. R., S. M. Grundy, and E. H. Ahrens, Jr. 1972. Cholesterol distribution in the bulk tissues of man: variation with age. J. Clin. Invest. 51:1292-1296.

38. Spady, D. K., and J. M. Dietschy. 1989. Interaction of aging and dietary fat in the regulation of low density lipoprotein transport in the hamster. J. Lipid. Res. 30:559-569.

39. Angelin, B., and K. Einarsson. 1986. Bile acids and lipoprotein metabolism. Atheroscler. Rev. 15:41-66.

40. Ballantyne, C. M., G. L. Vega, C. East, G. Richards, and S. M. Grundy 1987. Low density lipoprotein metabolism in cerebrotendinous xanthomatosis. Metab. Clin. Exp. 36:270-276.

41. Tint, G. S., H. Ginsberg, G. Salen, N.-A. Le, and S. Shefer. 1989. Chenodeoxycholic acid normalizes elevated lipoprotein secretion and catabolism in cerebrotendinous xanthomatosis. J. Lipid. Res. 30:633-640.

42. Rudman, D., M. H. Kutner, M. Rogers, M. F. Lubin, G. A. Fleming, and R. P. Baine. 1981. Impaired growth hormone secretion in the adult population. $J$. Clin. Invest. 67:1361-1369.

43. The Expert Panel. 1988. Report of the National Cholesterol Education Program Expert Panel on detection, evaluation, and treatment of high blood cholesterol in adults. Arch. Intern. Med. 148:36-69.

44. Gordon, D. J., and B. M. Rifkind. 1989. Treating high blood cholesterol in the older patient. Am. J. Cardiol. $63: 48 \mathrm{H}-52 \mathrm{H}$ 